\title{
Baveno VI Recommendation on Avoidance of Screening Endoscopy in Cirrhotic Patients: Are We There Yet?
}

\author{
Mário Jorge Silva ${ }^{\mathrm{a}, \mathrm{b}}$ Carlos Bernardes $^{\mathrm{a}}$ João Pinto ${ }^{\mathrm{a}}$ Rafaela Loureiro $^{\mathrm{a}}$ \\ Pedro Duarte $^{\mathrm{a}}$ Milena Mendes $^{\mathrm{a}}$ Filipe Calinas $^{\mathrm{a}}$ \\ ${ }^{a}$ Gastroenterology Department, Hospital de Santo António dos Capuchos, Centro Hospitalar de Lisboa Central,

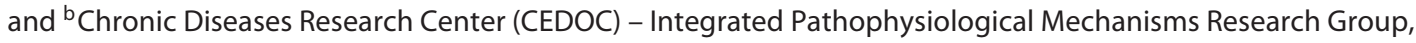 \\ Faculdade de Ciências Médicas, NOVA Medical School, Lisbon, Portugal
}

\section{Keywords}

Consensus · Elasticity imaging techniques · Endoscopy · Esophageal and gastric varices · Hypertension, portal · Liver cirrhosis

\section{Abstract}

Introduction: Recent studies assessed the predictive value of liver transient elastography, combined or not with platelet count, for the presence of esophageal varices in patients with liver cirrhosis, and multiple cutoffs have been proposed. The Baveno VI consensus states that patients with compensated advanced chronic liver disease, liver stiffness $<20 \mathrm{kPa}$, and a platelet count $>150,000$ have a very low risk of having varices requiring treatment and can avoid screening endoscopy. We aimed to validate this recommendation in a cohort of cirrhotic patients. Methods: Retrospective analysis of all patients evaluated at the Gastroenterology Department (Centro Hospitalar de Lisboa Central) between September 2009 and October 2015 with a liver stiffness (FibroScan ${ }^{\circledR}$ ) compatible with liver cirrhosis as well as upper endoscopy and blood tests within 12 months from elastography. Patients on propranolol $\geq 80 \mathrm{mg} /$ day or carvedilol $\geq 12.5 \mathrm{mg} /$ day, as well as those with previous variceal bleeding, variceal endoscopic treatments, or cirrhosis decompensations

\section{KARGER}

E-Mail karger@karger.com www.karger.com/pjg (c) 2016 Sociedade Portuguesa de Gastrenterologia Published by S. Karger AG, Basel Karcer Open access

This article is licensed under the Creative Commons AttributionNonCommercial-NoDerivatives 4.0 International License (CC BYNC-ND) (http://www.karger.com/Services/OpenAccessLicense) Usage and distribution for commercial purposes as well as any distribution of modified material requires written permission. were excluded. We validated the new Baveno VI recommendation and explored alternative cutoffs. Results: Ninety-seven patients were analyzed, 76.3\% (74/97) male, mean age $54.3 \pm 11.2$ years. Most patients $(55.7 \%)$ had no varices and $14.4 \%$ had varices requiring treatment. Most patients (78.4\%) had cirrhosis related to chronic hepatitis $C$. If the new Baveno $\mathrm{VI}$ recommendation had been applied to this cohort, upper endoscopy would have been avoided in $11.3 \%$ (11/97) of patients, none of them with esophageal varices requiring treatment: specificity $100 \%$, sensitivity $13.3 \%$, positive predictive value $100 \%$, and negative predictive value $16.3 \%$ for absence of varices requiring treatment. If screening endoscopy had been avoided in those patients with liver stiffness $<30$ $\mathrm{kPa}$ and platelet count $\geq 120,000$, endoscopy would have been avoided in $27.8 \%$ (27/97) of patients, none of whom with esophageal varices requiring treatment: specificity $100 \%$, sensitivity $32.5 \%$, positive predictive value $100 \%$, and negative predictive value $20 \%$ for absence of varices requiring treatment. Conclusions: The new Baveno VI criteria identified compensated cirrhotic patients without varices requiring treatment in whom screening endoscopy could have been avoided safely. Further studies are needed to confirm these findings and potentially explore more ambitious but still safe cutoffs for those criteria.

(C) 2016 Sociedade Portuguesa de Gastrenterologia Published by S. Karger AG, Basel 
Recomendação de Baveno VI Sobre Evicção da Endoscopia de Rastreio em Doentes com Cirrose: Já Lá Estamos?

\section{Palavras Chave}

Cirrose hepática · Consenso · Endoscopia · Hipertensão portal - Varizes esofágicas e gástricas · Técnicas de imagem por elasticidade

\section{Resumo}

Introdução: Estudos recentes avaliaram o valor preditivo da elastografia hepática transitória, combinada ou não com contagem plaquetária, para a presença de varizes esofágicas em doentes com cirrose hepática, e foram propostos vários valores de corte. O consenso de Baveno VI afirma que doentes com doença hepática crónica avançada compensada, elastografia hepática $<20 \mathrm{kPa} e$ $>150,000$ plaquetas têm muito baixo risco de varizes com necessidade de tratamento, podendo evitar endoscopia de rastreio. Pretendemos validar esta recomendação numa coorte de doentes cirróticos. Métodos: Análise retrospectiva dos doentes avaliados no Serviço de Gastrenterologia (Centro Hospitalar de Lisboa Central) entre Setembro 2009 e Outubro 2015 com elastografia hepática (FibroScan ${ }^{\circledR}$ ) compatível com cirrose hepática e análises num intervalo até 12 meses desde a elastografia. Doentes sob propranolol $\geq 80 \mathrm{mg} /$ dia ou carvedilol $\geq 12.5 \mathrm{mg} / \mathrm{dia}$, assim como aqueles com antecedentes de hemorragia variceal, tratamento endoscópico de varizes ou descompensação de cirrose foram excluídos. Validámos a nova recomendação de Baveno VI e explorámos valores de corte alternativos. Resultados: Noventa e sete doentes foram analisados, 76.3\% (74/97) homens, idade média $54.3 \pm 11.2$ anos. A maioria dos doentes (55.7\%) não tinha varizes, $14.4 \%$ tinha varizes com indicação para tratamento. A maioria dos doentes (78.4\%) tinha cirrose relacionada com hepatite $C$. Se a nova recomendação de Baveno $\mathrm{VI}$ tivesse sido aplicada nesta coorte, a endoscopia de rastreio teria sido evitada em $11.3 \%$ (11/97) dos doentes, nenhum com varizes com indicação para tratamento: especificidade $100 \%$, sensibilidade $13.3 \%$, valor preditivo positivo $100 \%$ e valor preditivo negativo $16.3 \%$ para ausência de varizes com indicação para tratamento. Se a endoscopia de rastreio fosse evitada nos doentes com elastografia hepática $<30 \mathrm{kPa}$ e $>120,000$ plaquetas, teria sido evitada em $27.8 \%$ (27/97) destes doentes, nenhum com varizes com indicação para tratamento: especificidade 100\%, sensibilidade
$32.5 \%$, valor preditivo positivo $100 \%$ e valor preditivo negativo 20\% para ausência de varizes com indicação para tratamento. Conclusão: Os novos critérios de Baveno VI identificaram doentes com cirrose compensada e sem varizes com indicação para tratamento, em que se podia ter evitado com segurança a endoscopia de rastreio. São necessários mais estudos para confirmar estes resultados e explorar valores de corte mais ambiciosos, mas seguros.

๑) 2016 Sociedade Portuguesa de Gastrenterologia Publicado por S. Karger AG, Basel

\section{Introduction}

Portal hypertension is a progressive complication of liver cirrhosis, and varices and variceal bleeding are its most direct consequences [1]. Gastroesophageal varices are present in approximately $50 \%$ of cirrhotic patients, and their existence correlates with severity of disease. The most important complication of varices is variceal bleeding, occurring in $25-40 \%$ of patients with cirrhosis [2] and associated with around 15\% mortality [3]. The risk of variceal bleeding depends on several factors, including size and appearance of varices and cirrhosis stage [1]. Therefore, patients with varices with high-risk features should be identified, so that treatment (primary prophylaxis of variceal bleeding) may be initiated.

Until recently, all clinical guidelines recommended that every cirrhotic patient should be screened for varices with the gold standard - upper gastrointestinal endoscopy $[1,4]$, and a recent guideline on noninvasive tests for liver disease highlighted that upper endoscopy cannot be replaced by noninvasive methods [5].

Nevertheless, several studies on the prediction of clinically significant portal hypertension $(\mathrm{CSPH})$ with noninvasive methods have been performed recently, and the report from the Baveno VI Consensus Workshop (held on April 2015) states that patients with compensated advanced chronic liver disease with a liver stiffness $<20 \mathrm{kPa}$ and a platelet count $>150,000$ have a very low risk of having varices requiring treatment and can avoid screening endoscopy [6].

We aimed to validate this new Baveno VI recommendation in a cohort of cirrhotic patients.
Silva/Bernardes/Pinto/Loureiro/Duarte/ Mendes/Calinas 
Table 1. Patient characteristics

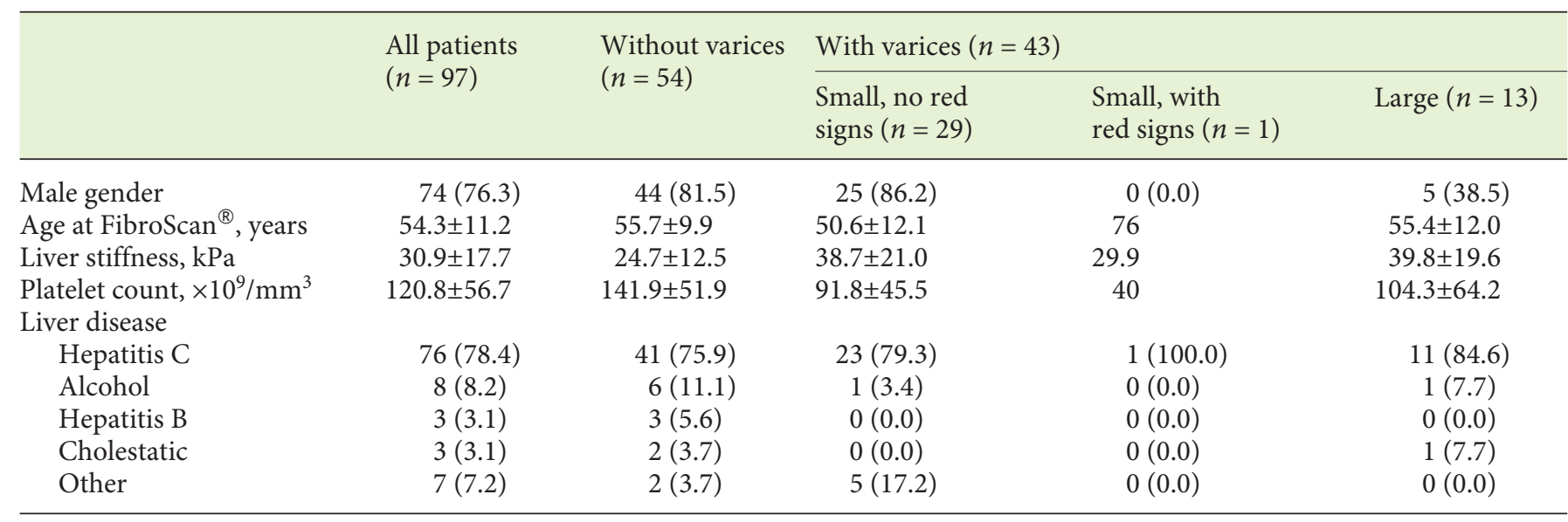

Values are $n(\%)$ or mean \pm standard deviation.

\section{Materials and Methods}

We performed a retrospective, single-center analysis of all patients evaluated at the Gastroenterology Department of the Centro Hospitalar de Lisboa Central between September 2009 and October 2015 with liver stiffness compatible with liver cirrhosis $(>12.5$ $\mathrm{kPa}$ ) and upper endoscopy as well as platelet count performed within 12 months from liver stiffness evaluation.

All evaluations were performed at the Centro Hospitalar de Lisboa Central (liver stiffness evaluation and upper gastrointestinal endoscopy at the Gastroenterology Department, platelet count at the Central Laboratory). Liver stiffness was evaluated with transient elastography (FibroScan ${ }^{\circledR}$ model 502, Echosens ${ }^{\circledR}$, Paris, France), performed by experienced users, and validated according to current recommendations. Upper endoscopy was performed by experienced endoscopists, and esophageal varices were classified as small (comprising grade $\mathrm{I} /$ small varices) or large (comprising grade II/medium and grade III/large varices) [1]. Patient records were reviewed for cirrhosis etiology and stage, as well as past and current treatments.

Patients on treatment for portal hypertension (propranolol $\geq 80 \mathrm{mg}$ /day or carvedilol $\geq 12.5 \mathrm{mg} /$ day), as well as patients with previous variceal bleeding or treatments (such as banding or sclerosis) were excluded. Decompensated cirrhotic patients (with ascites, hepatic encephalopathy, Child-Pugh class B, or Child-Pugh class C) were excluded as well.

Esophageal varices requiring treatment were defined, according to Baveno VI, as small varices with red signs or large varices [6].

Statistical analysis was performed with Microsoft Office Excel ${ }^{\circledR}$ 2010 and STATA ${ }^{\circledR}$ v12.1. Descriptive univariate analysis was performed and is reported as means and standard deviations for continuous variables and proportions for categorical variables.

\section{Results}

A total of 97 patients were analyzed, 76.3\% (74/97) male, with a mean age of $54.3 \pm 11.2$ years at liver elastography. Most patients (55.7\%) had no varices, $29.9 \%$ had small varices without red signs, $1.0 \%$ had small varices with red signs, and $13.4 \%$ had large varices - therefore, $14.4 \%$ (14 patients) had varices requiring treatment. All patients were Child-Pugh class A, and most (78.4\%) had cirrhosis related to chronic hepatitis C. Population characteristics are detailed in Table 1.

If the new Baveno VI recommendation had been applied to this cohort of cirrhotic patients, upper endoscopy would have been avoided in $11.3 \%$ (11/97) of patients, none of them with esophageal varices requiring treatment (2 patients had small varices without red signs and 9 patients had no varices). Upper endoscopy would have been performed in $88.7 \%(86 / 97)$ of patients $-52.3 \%(56 / 86)$ of whom had no varices - and would have identified all patients with varices requiring treatment.

The Baveno VI criteria had a specificity of $100 \%$ (95\% CI $76.8-100 \%$ ), a sensitivity of $13.3 \%$ (95\% CI $6.81-$ $22.5 \%$ ), a negative likelihood ratio of 0.87 (95\% CI $0.80-$ 0.94 ), a positive predictive value of $100 \%$ (95\% CI $71.5-$ $100 \%$ ), and a negative predictive value of $16.3 \%$ (95\% CI 9.2-25.8\%) for absence of varices requiring treatment.

From this cohort, it is possible to generate alternative criteria based on liver elastography and platelet count to identify patients without varices requiring treatment. If screening endoscopy had been avoided in those patients with liver stiffness $<30 \mathrm{kPa}$ and platelet count $\geq 120,000$, 
endoscopy would have been avoided in 27.8\% (27/97) of patients, none of whom with esophageal varices requiring treatment ( 3 patients had small varices without red signs and 24 patients had no varices). Screening endoscopy would have been performed in $61.9 \%$ patients and would have identified all patients in the cohort with varices requiring treatment.

This new criteria (avoiding screening endoscopy when liver stiffness $<30 \mathrm{kPa}$ and platelet count $\geq 120,000$ ) in this derivation cohort had a specificity of $100 \%$ (95\% CI 76.8$100 \%$ ), a sensitivity of $32.5 \%$ (95\% CI $22.6-43.7 \%$ ), a negative likelihood ratio of 0.68 (95\% CI $0.58-0.78$ ), a positive predictive value of $100 \%$ (95\% CI $87.2-100 \%)$, and a negative predictive value of $20.0 \%$ (95\% CI $11.4-31.3 \%$ ) for absence of varices requiring treatment.

\section{Discussion}

There is a clear potential of noninvasive methods to identify cirrhotic patients with low risk of having varices requiring treatment and that therefore could avoid unpleasant screening endoscopies - relatively invasive procedures with associated risks and costs.

Liver stiffness has been shown to correlate with hepatic venous pressure gradient (HVPG) [7]. Many studies assessed the predictive value of liver elastography (alone [8] or in combination with other noninvasive measures) $[9,10]$ and platelet count $[11-13]$ for CSPH. Nevertheless, several different surrogate markers of CSPH have been used in those studies (i.e., HVPG, presence of varices, presence of large varices), and their results may not be directly comparable.

In general, proposed cutoffs for liver stiffness predict presence and size of esophageal varices with high sensitivities but rather unsatisfactory specificities [5]. In fact, it is probable that liver stiffness performs much better at ruling out varices than ruling them in. Correlation between liver stiffness and HVPG is excellent for HVPG values lower than 10-12 $\mathrm{mm} \mathrm{Hg}$, but is suboptimal for higher HVPG values [14]. This is explained by the fact that with cirrhosis progression, the mechanisms of portal hypertension become less dependent on the intrahepatic resistance to portal flow due to tissue fibrosis (measured by liver elastography) and progressively more dependent on extrahepatic factors, such as hyperdynamic circulation and splanchnic vasodilation [5]. Therefore, liver stiffness may probably perform better at identifying patients without varices (i.e., with HVPG below 10-12 $\mathrm{mm} \mathrm{Hg}$ ) [1] than at identifying patients with large varices, or varices with red signs, the latter presumably having HVPG values that do not correlate well with liver stiffness values.

The 2015 Baveno VI Consensus Workshop published the first consensus recommendation on avoidance of screening endoscopy in patients with compensated advanced liver disease in an era where evidence in this field was probably not robust enough. The concept of "compensated advanced chronic liver disease" is, per se, innovative, and may be suspected based on liver transient elastography evaluation: values between 10 and $15 \mathrm{kPa}$ are suggestive and values $>15 \mathrm{kPa}$ are highly suggestive of compensated advanced chronic liver disease. Furthermore, this new concept and its definition are independent of the etiology of liver disease [6].

In our study, we found that Baveno VI criteria identified correctly patients without varices requiring treatment and would have allowed safe avoidance of screening endoscopy in $11 \%$ of this cohort of compensated cirrhotic patients. Nevertheless, robust data on this issue are lacking. It is possible that less stringent criteria will allow to safely avoid a greater proportion of screening endoscopies in low-risk patients in the future, rendering this management strategy even more cost-effective. The new criteria generated from this cohort are speculative and not generalizable, but demonstrate that further cutoffs may be explored.

Our study has several limitations, and our results should be interpreted carefully. This was a single-center, retrospective study, based on liver stiffness measures and endoscopies performed by different operators (although all of them were experienced). Liver stiffness measures were based on single determinations and not confirmed, as recently proposed [6]. A liver stiffness cutoff $\geq 12.5 \mathrm{kPa}$ [15] was used to define liver cirrhosis irrespective of the etiology of liver disease. Indeed, alternative cutoffs for nonviral liver diseases are insufficiently validated [5], and even for alcohol-related liver disease, presumably associated with higher transient elastography values [5], the proposed cutoff for cirrhosis is $12.5 \mathrm{kPa}$ [16]. Furthermore, the Baveno VI criteria do not recommend differential cutoffs for diagnosis of "compensated advanced chronic liver disease" according to the etiology of liver disease [6].

These Baveno VI criteria performed similarly well (negative predictive value 100\%) in some studies [17-19], but failed to identify few patients with varices requiring treatment in other ones (negative predictive value 91.2$98 \%)[20,21]$. It is important to note that prevalence of varices varied between studies, which were therefore prone to spectrum bias.
Silva/Bernardes/Pinto/Loureiro/Duarte/ Mendes/Calinas 
In this study, we did not account for the diagnosis of other unsuspected diseases (as gastric antral vascular ectasia, peptic ulcer, or gastric cancer) and surrogate markers of CSPH (as small esophageal varices) in screening endoscopies, which obviously would have a significant impact on patient management and outcomes.

\section{Conclusions}

The Baveno VI criteria based on liver stiffness $(<20$ $\mathrm{kPa})$ and platelet count $(>150,000)$ identified correctly compensated cirrhotic patients without varices requiring treatment in this cohort (in whom screening endoscopy could have been safely avoided), but allowed for avoidance of endoscopy only in a small proportion of patients.
Further studies, with larger sample sizes, less heterogenous cirrhosis etiologies, and preferentially prospective design, are needed to confirm these findings and potentially explore more robust and cost-effective cutoffs for liver stiffness and platelet count.

\section{Statement of Ethics}

This study did not require informed consent nor review/approval by the appropriate ethics committee.

\section{Disclosure Statement}

The authors have no conflicts of interest to declare.

\section{References}

1 Garcia-Tsao G, Sanyal AJ, Grace ND, Carey W; Practice Guidelines Committee of the American Association for the Study of Liver Diseases, Practice Parameters Committee of the American College of Gastroenterology: Prevention and management of gastroesophageal varices and variceal hemorrhage in cirrhosis. Hepatology 2007;46:922-938.

2 Grace ND: Prevention of initial variceal hemorrhage. Gastroenterol Clin North Am 1992; 21:149-161.

3 Carbonell N, Pauwels A, Serfaty L, Fourdan O, Lévy VG, Poupon R: Improved survival after variceal bleeding in patients with cirrhosis over the past two decades. Hepatology 2004; 40:652-659.

4 de Franchis R; Baveno V Faculty: Revising consensus in portal hypertension: report of the Baveno V consensus workshop on methodology of diagnosis and therapy in portal hypertension. J Hepatol 2010;53:762-768.

5 European Association for Study of Liver; Asociacion Latinoamericana para el Estudio del Higado: EASL-ALEH Clinical Practice Guidelines: Non-invasive tests for evaluation of liver disease severity and prognosis. J Hepatol 2015;63:237-264.

6 de Franchis R; Baveno VI Faculty: Expanding consensus in portal hypertension: report of the Baveno VI Consensus Workshop: stratifying risk and individualizing care for portal hypertension. J Hepatol 2015;63:743-752.

7 Bureau C, Metivier S, Peron JM, Selves J, Robic MA, Gourraud PA, et al: Transient elastography accurately predicts presence of significant portal hypertension in patients with chronic liver disease. Aliment Pharmacol Ther 2008;27:1261-1268.

8 Shi KQ, Fan YC, Pan ZZ, Lin XF, Liu WY, Chen YP, et al: Transient elastography: a me- ta-analysis of diagnostic accuracy in evaluation of portal hypertension in chronic liver disease. Liver Int 2013;33:62-71.

$9 \mathrm{Hu}$ Z, Li Y, Li C, Huang C, Ou Z, Guo J, et al: Using ultrasonic transient elastometry (FibroScan) to predict esophageal varices in patients with viral liver cirrhosis. Ultrasound Med Biol 2015;41:1530-1537.

10 Shibata S, Umemura T, Yamazaki T, Fujimori N, Ichikawa Y, Kimura T, et al: Liver stiffness-spleen size-to-platelet ratio risk score identifies esophageal varices in Japanese patients with chronic hepatitis C. Hepatol Res 2016;46:884-889.

11 Cástera L, Le Bail B, Roudot-Thoraval F, Bernard PH, Foucher J, Merrouche W, et al: Early detection in routine clinical practice of cirrhosis and oesophageal varices in chronic hepatitis C: comparison of transient elastography (FibroScan) with standard laboratory tests and non-invasive scores. J Hepatol 2009; 50:59-68.

12 Thomopoulos KC, Labropoulou-Karatza C, Mimidis KP, Katsakoulis EC, Iconomou G, Nikolopoulou VN: Non-invasive predictors of the presence of large oesophageal varices in patients with cirrhosis. Dig Liver Dis 2003;35: 473-478.

13 Zaman A, Becker T, Lapidus J, Benner K: Risk factors for the presence of varices in cirrhotic patients without a history of variceal hemorrhage. Arch Intern Med 2001;161:2564-2570.

14 Vizzutti F, Arena U, Romanelli RG, Rega L, Foschi M, Colagrande S, et al: Liver stiffness measurement predicts severe portal hypertension in patients with HCV-related cirrhosis. Hepatology 2007;45:1290-1297.

15 Pang JX, Zimmer S, Niu S, Crotty P, Tracey J, Pradhan F, et al: Liver stiffness by transient elastography predicts liver-related complica- tions and mortality in patients with chronic liver disease. PLoS One 2014;9:1-9.

16 Pavlov CS, Casazza G, Nikolova D, Tsochatzis E, Gluud C: Systematic review with metaanalysis: diagnostic accuracy of transient elastography for staging of fibrosis in people with alcoholic liver disease. Aliment Pharmacol Ther 2016;43:575-585.

17 Thabut D, Bureau C, Layese R, Bourcier V, Corvy L, Petrov-Sanchez V, et al: New recommendations of Baveno VI conference for the screening of portal hypertension: an independent sequential validation in patients with compensated viral cirrhosis taking into account virological status (ANRS CO12 CIRVIR cohort). J Hepatol 2016;64(suppl 2):S178.

18 Paternostro R, Schwarzer R, Ferlitsch $M$, Schwalb P, Reiberger T, Mandorfer M, et al: Exclusion of varices via transient elastography combined with platelet count according to the Baveno VI guidelines can only be made for large not small varices. J Hepatol 2016; 64(suppl 2):S283.

19 Perazzo H, Fernandes FF, Castro Filho EC, Perez RM: Points to be considered when using transient elastography for diagnosis of portal hypertension according to the Baveno's VI consensus. J Hepatol 2015;63:10481049.

20 A Chang PEJ, Cheah CCM, Li WJ, Wong YE: Real-world validation of Baveno VI recommendations for screening endoscopy in patients with compensated advanced chronic liver disease. J Hepatol 2016;64(suppl 2):S178. 21 Maurice JB, Brodkin E, Arnold F, Paine H, Navaratnam AMD, Khawar S, et al: The Baveno VI guidelines: can we confidently identify low risk cirrhotic patients not requiring endoscopic surveillance for varices? J Hepatol 2016;64(suppl 2):S725. 